\title{
The Development of Subject Specific Pedagogy with SETS Vision to Improve Science Process Skills and Learning Motivation
}

\author{
Erwin Prastyo \\ Science Education, Post Graduate Program, Universitas Negeri Semarang \\ J1. Kelud Utara III Semarang 50237 \\ Email: erwinprastyo@students.unnes.ac.id
}

\begin{abstract}
The aims of this research are to develop Subject Specific Pedagogy with SETS vision that consist of syllabus, lesson plans, students worksheets, and evaluation sheets that can be applied in teaching learning to develop science process skills and learning science motivation for seventh grade students in Junior High School. The study was a Research and Development (R\&D) with students in class VII MTs Darul Ishlah Sukorejo as a subject of study. The research start from September to November 2019. The study began with a literature study and field study to obtain information about the problem faced at school, and followed by planning, drafting and validating product by experts. The result shows that Subject Specific Pedagogy with SETS vision feasible to use in teaching and learning based on the validation result from lecturer, teacher, and student response. The Subject Specific Pedagogy with SETS vision potential for develop the science process skills and learning science motivation of students.
\end{abstract}

Keywords: Subject Specific Pedagogy, SETS vision, science process skills, learning motivation.

\section{INTRODUCTION}

Science is related to how to systematically find out about nature, so that science is not only mastering a collection of knowledge in the form of facts, concepts, or principles, but also a process of discovery. Science is expected to be a vehicle for students to learn about themselves and their natural surroundings, as well as prospects for further development in applying them in their daily life (Depdiknas, 2006).

The integrated learning approach in science is often referred to as an interdisciplinary approach. Integrated learning model is essentially a learning model that allows students both individually and in groups to actively seek, explore, and discover concepts and principles holistically and authentically (Trianto, 2010). One of them is integrating basic competencies. Through integrated learning students can get direct experience, so that they can add strength to receive, store, and produce impressions about the things they learn.

One of the most important and pervasive goals of schooling is to teach students to think. All school subjects should share in accomplishing this overall goal. Science contributes its unique skills, with its emphasis on hypothesizing, manipulating the physical world and reasoning from data.

Science process skills according to Rustaman (2014) science process skills is a set of skills used by scientists in conducting scientific investigations. These science process skills can be divided into a number of skills a process that needs to be mastered if someone wants to develop scientific knowledge and methods. The scientific method, scientific thinking and critical thinking have been terms used at various times to describe these science skills. Today the term science process skills is commonly used.

Carin (Rustaman, 2014) suggests several reasons for its importance process skills. First, in practice what is known in science is inseparable from the method of inquiry. Knowing science is not just about knowing material about science course but also related to understanding how to gathering facts and linking facts to make a point interpretation or conclusion. Second, science process skills are lifelong learning skills (life long learning) that you can used not only to study science but can also be used in everyday life, even to be able to survive (life skills).

Binadja (2002) states that in SETS visionary learning, teachers and students share an important role in achieving learning goals. Through the SETS approach it is expected that students view things integrally, namely by paying attention to the elements in SETS. The teacher can relate the concepts of science taught by paying attention to the elements contained in SETS. The teacher can relate scientific concepts to the problems that occur in the community, the daily environment of students so that they can help students apply the results of their learning in everyday life so that learning in schools is beneficial for the community by paying attention to their impact on the environment. Smoothness and success in learning can be supported by the availability of more varied learning facilities. Learning tools as an alternative teaching material that can be utilized are Subject Specific Pedagogy. Students' worksheets is one of the teacher's handles in the form of sheets containing assignments that must be done by students. 
The SETS approach is an approach that can link material with science, environment, technology and society. Zahra, et al (2018) explains that the science process skills within oneself learners can be built with using a learning-based approach SETS (Science, Environment, Technology, and Society). Subject Specific Pedagogy with SETS vision used in science learning are contextually packaged that is associated with students' lives get goals open insight and improve science process skills. Students' worksheets with SETS vision as one of the learning tools that will be applied to train students' science process skills in accordance with the learning material. From the above, it is necessary to do research for improve science process skills of students in linking science with the environment, technology, and society. The purpose is to (1) develop Subject Specific Pedagogy with SETS vision; (2) find out the feasibility of Subject Specific Pedagogy with SETS vision developed; (3) know the potential Subject Specific Pedagogy with SETS vision develop the student science process skills and learning science motivation of students.

\section{MATERIALS AND METHODS}

This research is research development. The development model used in this study refers to the 4D model. Development procedure consists of 4 major phases: define, design, develop, and dessiminate (Thiagarajan, et $a l, 1974)$ but in this study was carried out 3 phase that is just to develop at this stage. Systematics research development proposed is as follows:

a. Define

The define stage is to obtain information about the needs that exist in the field to help develop existing Subject Specific Pedagogy. Research and information collection: analyze curriculum, learning conditions, environmental learning conditions, environmental society conditions and the character of students.

b. Design

The design stage is done to design a prototype product development. The prototype is a preliminary draft which is the basic form of product development. Planning: design the Subject Specific Pedagogy and designing instruments to measure quality the Subject Specific Pedagogy.

c. Develop

Develop preliminary the form of product: develop Subject Specific Pedagogy, design validation, and revision. The aim of this development stage is to modify the prototype with the evaluation and revision before it becomes effective product.

d. Dvvata Analysis

The data that obtained in this research is the development of qualitative and quantitative data.

\section{Data analysis}

The technique validation for data analysis was done with the steps as presented by Arun Azwar (2011: 163) which includes: (1) compare all data obtained from the validator for each component of the assessment of grain available in the assessment instruments, (2) to calculate the average score of each component, and (3) change the average score into a value with criteria. Subject Specific Pedagogy with SETS vision stated worth is used if the average score of each Subject Specific Pedagogy component has a good category. Score conversion became 5 scale is presented in Table 1. The results presented in Table 2.

Table 1. Conversion score validation.
\begin{tabular}{ccl} 
Interval Score & Value & \multicolumn{1}{c}{ Category } \\
$3.25<\mathrm{X}$ & $\mathrm{A}$ & Very good \\
$2.75<\mathrm{X} \leq 3,25$ & $\mathrm{~B}$ & Cood \\
$2.75<\mathrm{X} \leq 3,25$ & $\mathrm{C}$ & Enough \\
$2.75<\mathrm{X} \leq 3,25$ & $\mathrm{D}$ & Less \\
$\mathrm{X} \leq 1.75$ & E & Very Less
\end{tabular}

\section{RESULTS AND DISCUSSION}

Based on the results of the validation by two validators (1 lecturer and 1 teacher), it is known that the Subject Specific Pedagogy developed in the very good category. However, the need for improvements to revision. The revision carried out on the advice and input of the validator. There is an input that is submitted in compliance with the terms of the technical aspects. Comparison of the results of the validation are indeed these aspects have the lowest value compared to other aspects, although still in the very good category. Most entries are associated layout, the use of the font. In addition, in terms of the presentation of the contents of the input or advice given is about the consistency of writing a bibliography. Subject Specific Pedagogy in different subjects, different shape. Subject Specific Pedagogy in science generally contains a guide to the activities of the investigations or experiments, table data, and issues that need to be discussed, students from the data the results of the experiment.

Table 2. The results of the validation of Subject Specific Pedagogy.

\begin{tabular}{llc}
\hline \multicolumn{1}{c}{ Feasibility Aspects } & Score & Category \\
\hline The Suitability Of The Material Requirement & 3.94 & Very Good \\
\hline The Suitability Of The Material Requirement & 3.79 & Very Good \\
\hline The Suitability Of The Construction Terms & 3.83 & Very Good \\
\hline The Suitability Of The Construction Terms & 3.66 & Very Good \\
\hline
\end{tabular}


Table 3. The students response.

\begin{tabular}{rlc}
\hline No. & \multicolumn{1}{c}{ Aspects } & Nverage \\
\hline $\mathbf{1}$ & Conformity with the requirements of & 3.1 \\
\hline $\mathbf{2}$ & Theme Concept relate to everyday life & 3.5 \\
\hline $\mathbf{3}$ & Benefï adds insight knowledge & 3.7 \\
\hline $\mathbf{4}$ & $\begin{array}{l}\text { The activities are presented in a worksheet Guide to learn integrated science } \\
\text { (biology, physics, chemistry) }\end{array}$ & 3.2 \\
\hline $\mathbf{5}$ & Interest in worksheet activity & 3.2 \\
\hline $\mathbf{6}$ & Readability of the language used & 3.6 \\
\hline $\mathbf{7}$ & The clarity of the writing language & 3.3 \\
\hline $\mathbf{8}$ & Ease of understanding the language used & 3.1 \\
\hline $\mathbf{9}$ & Adequacy of the space provided to write in worksheet & 3.1 \\
\hline No. & \multicolumn{1}{c|}{ Aspects } & Nverage \\
\hline $\mathbf{1 0}$ & The worksheet layout & 3.3 \\
\hline $\mathbf{1 1}$ & The clarity of images, tables, and illustrations used & 3.5 \\
\hline $\mathbf{1 2}$ & Intriguing learning & 3.3 \\
\hline
\end{tabular}

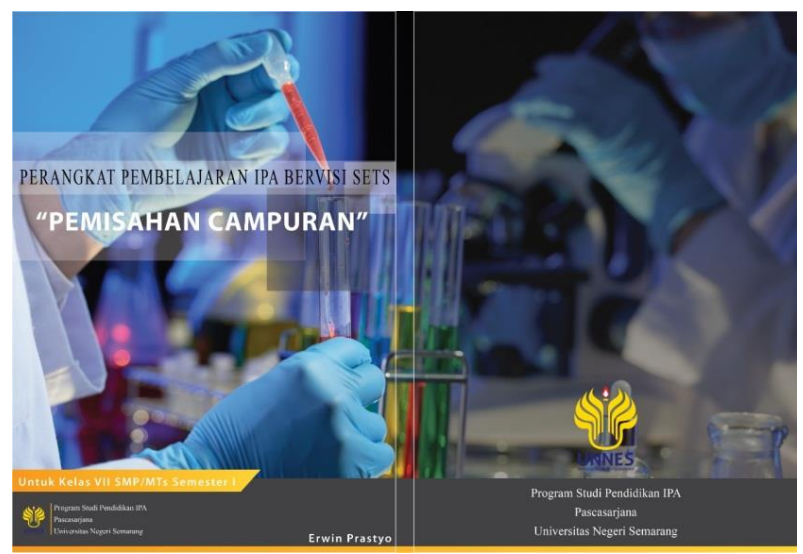

Figure 1. The cover Subject Specific Pedagogy with SETS vision "Pemisahan Campuran.

Subject Specific Pedagogy with SETS vision was developed can also develop a science process skills and learning science motivation of students. Based on the results of the assessment, all the validator declares that the assignment and student activities contained in Subject Specific Pedagogy with SETS vision cultivate the skills students pushing process student include observing, classifying, conclude, and communicate.

Aside from the validator, before being used in field feasibility the students worksheets with SETS vision well as determined by student response after reading worksheet 10 respondents (students) is worksheet distributed, then asked to fill out the question form provided. The average student response against about students worksheets. The results presented at table 3 . Refers to the conversion of the score on table 1 , it can be seen that all the components is in good category.

\section{CONCLUSIONS}

The conclusions that can be drawn from this study were as follows:
1. The process of developing a Subject Specific Pedagogy with SETS vision performed using 4D has been simplified into 3D, that Define, Design, and Develop.

2. Subject Specific Pedagogy with SETS vision that developed very good category and worthy of use in learning.

3. Subject Specific Pedagogy with SETS vision potentially develop science process skills and learning science motivation of students.

\section{REFERENCES}

Ariyanti, L.S. \& Wilujeng, I. 2018. Pengembangan Perangkat Pembelajaran Berbasis SETS untuk Meningkatkan Motivasi dan Menumbuhkan Sikap Peduli Lingkungan. Jurnal Pendidikan Matematika dan Sains, VI (2): 102-113.

Apriliyanti, D.D., Haryani, S. \& Widiyatmoko, A. 2015. Pengembangan Alat Peraga IPA Terpadu pada Tema Pemisahan Campuran untuk Meningkatkan Keterampilan Proses Sains. Unnes Science Education Journal, 4 (2): 835841.

Binadja, A. 2002. Pemikiran dalam SETS (Science, Environment, Technology, and Society). Pascasarjana UNNES, Semarang.

Chiappetta, E.L. \& Koballa, T.R. 2010. Science Instruction in the Middle and Secondary Schools. Boston: Allyn \& Bacon.

Depdiknas. 2006. Panduan Pengembangan Pembelajaran IPA Terpadu SMP/MTs. Puskur Balitbang Depdiknas, Jakarta.

Hardiyanti, P.C., Wardani, S., \& Nurhayati, S. 2017. Keefektifan Model Problem based Learning untuk Meningkatkan Keterampilan Proses Sains Siswa. Jurnal Inovasi Pendidikan Kimia, 11 (1): 1862-1871.

Maulina, Adlim, \& Mudatsir. 2016. Pengembangan LKPD Pemisahan Campuran Berbasis PBL terhadap Keterampilan Proses Sains dan Hasil Belajar Peserta Didik MTsN 1 Geumpang. Jurnal Pendidikan Sains Indonesia, 4 (1): 107116.

Padilla, M.J. 1990. The Science Process Skills. National Association for Research in Science Teaching, Canada.

Rustaman, N. 2014. Materi dan Pembelajaran IPA SD. Universitas Terbuka, Jakarta. 
Thiagarajan, S., Semmel, D.S., \& Semmel, M.I. 1974. Instructional Development for Training Teachers of Exceptional Children. Indiana University Bloomington, Indiana.

Trianto. 2010. Model Pembelajaran Terpadu: Konsep, Strategi, dan Implementasinya dalam KTSP. Bumi Aksara, Jakarta.
Zahra, M., Wati, W., \& Makbuloh, D. 2019. Pembelajaran SETS (Science, Environment, Technology, Society): Pengaruhnya pada Keterampilan Proses Sains. Indonesian Journal of Science and Mathematic Education, 2 (3): 320-327. 